\title{
Political Parties in MENA: their Functions and Development
}

\author{
Raymond Hinnebusch \\ University of St Andrews
}

\begin{abstract}
This article provides an overview of the development of parties and party systems in the MENA region from early oligarchic pluralism to the mass single party systems of the populist era and the limited multi-party experiments of the 1990s era of political liberalization. The survey shows how parties develop in parallel with the deepening of politicization and become nearly-indispensable adjuncts in the construction of political order. The article then examines parties in the post-2010 period, with case studies of Turkey, Egypt, and Tunisia demonstrating how very different configurations of party development dramatically impact on regime trajectories, ranging from democratization to hybrid regimes.
\end{abstract}

Political parties are often said to matter little in the Middle East and North Africa, where monarchs or the military tend to subordiante or marginalize parties.. Moreover, with a disproportionate number of no-party, one party or dominant party states, the region suffers from a deficit of the party competition associated with democracy.

Bill and Springborg offered a "political culture" explanation for this: the continued viability of traditional solidarity groups (kinship groups, shillas) and of clientalism and tribalism as alternative mechanisms of elite-mass linkage, both of which deter and colonize more inclusive forms of impersonal association. An alternative structural explanation points to the pre-emption of political space by the prior external imposition (and subsequent channelling of oil "rent" through) the bureaucratic and military arms of the state, allowing it to subordinate or corporatize political structures, including parties, which would otherwise have represented civil society or mobilized class constituencies. ${ }^{1}$

To the extent this is so, it may go far to explaining the dysfunction of MENA political systems for it may be taken as one of the few "laws" of political science that the healthy operation of modern polities requries political parties. Only parties, with their unique capacity to organize large numbers of citizens behind leaders with a governing program, potentially give ordinary people a voice in governance that can balance the oligarchic minorities who wield monopolies of money, guns or traditional status. Mass class-based parties were the main vehicles by which political participation was widened in the West. And it is parties that provide the consistent organized support needed if governments are to effectively govern.

\section{Why Political Parties in the Middle East Matter}

The Middle East is not, however, entirely "exceptional" in respect to parties. Organizations with a family resemblance to parties exist in two-thirds of Arab states and while their roles may be more marginal than in developed states, similar structures are unlikely to perform wholly dissimilar functions in a political system. To be sure, parties reflect the political culture of their societies: the power of substate identities and small group politics is manifest in the tendency of parties to form and fragment around personalities, clans and sects. At the same time, however, culture is amenable to change and once traditional legitimacy eroded, newly emergent elites in MENA soon adopted a new "political technology"--party ideology 
and organization-in order to mobilize support for their agendas. ${ }^{2}$ Parties were major instruments for the spread of politicization further down in the stratification system--from oligarchy to middle class to masses-and, in the process they, in turn, evolved beyond the personal factions of notables though the adoption of the party organization needed to incorporate widening numbers of participants: in the first stage, branches appeared in the provincial towns dominated by educated professionals and civil servants, later, cells in factories and villages brought in workers and peasants. In parallel, as party recruitment widened to include activists of middle and then lower class origin, the ideologies of parties came to appeal to wider constituencies, promoting more egalitarian and reformist programs, potentially changing the balance of social class power.in MENA societies.

Party systems were also decisive for the changing character of regimes in the region. Party formation enabled the mass mobilization against colonial rulers that helped win independence for many Arab countries, with the Egyptian Wafd the prototype. The potential of the liberal oligrachies that took power after independence to consoldate early fragile democracies through mass inclusion was aborted because their party systems were too fragmented or polarized to widen participation and manage peaceful change; the outstanding exception, the transformation to democracy achieved in 1950s Turkey was dependent on the emergence of two relatively equal parties sufficiently close in ideology for each to accept democratic electoral competition over power. The failure of democratization in the Arab world opened the way for the 1960s dominance of populist authoritarian regimes which used ruling single parties, "the modern form of authoritarianism," 3 to carry out revolution from above and mobilize the constituencies needed to consolidate themselves against the old oligarchy. Then, as single parties ran out of ideological steam, parallel to the 1980s shift from populist to post-populist versions of authoritarianism pursuing neo-liberal policies, elites turned single parties from instruments of mobilization into mechanisms of clientalism and demobilization, used to contain mass resistance to neo-liberal reforms. However, the political vacuum created was quickly filled by Islamist political movements seeking to mobilize the victims of post-populism and forcing further regime adaptation. In the 1990s, as part of strategies of "authoritarian upgrading," regimes sought to coopt increasing opposition, both Islamist and liberal, through limited pluralization of party systems, in which the ruling party was flanked by smaller opposition parties of the left and right. For this to lead to democratization, opposition parties had to become mass organizations, but their failure, with few exceptions, to do so, in this period and also in the brief opportunities opened by the Arab uprising, helps explain the Middle East's continuing democracy deficit. Crucial to the only successful democratization issuing from the post 2010 Arab Uprisings, that of Tunisia, was the emergence of a competitive two party system.

The following discussion traces party development over several stages, namely, the eras of liberal oligarchy; populist revolution; post-populist authoritarianism; and Arab Uprising. The narrative will show both that party systems were shaped by the features of the stage, notably whether politicization and inclusion were widening or contracting, but also how parties were important factors in both the levels of consolidation of regimes at each stage and in the transitions to subsequent stages. Case studies of countries where parties played such important 
roles bridge the four stages to illustrate the interaction of regime formation and party systems over time. While the evolving pattern of party change was most pronounced in the authoritarian republics, comparing them to the somewhat different party trajectories of those monarchies that allowed party formation and with democracies (with Lebanon distinct from Turkey and Israel) underlines the intimate interrelation of regime and party development .

\section{Party Development}

Early party pluralism under liberal oligarchies

This stage spanned a period beginning around 1900, when political contestation emerged within a small oligarchic political arena, and usually ended in the fifties or sixties when the mobilization of middle class activism.

The earliest precursors of political parties appeared in the late Ottoman period when groupings of officers, bureaucrats or professionals formed to press for modernization, constitutional rule (The Committee of Union and Progress) or Arab rights within the empire (al-Ahd). The collapse of the empire led to a proliferation of nationalist parties seeking to fill the ideological vacuum, notably the Fatat party that backed the short lived Faisal government in Damascus. Under Western imperialism and early independence, parties of "notables" dominated; parties were the instruments of small groups of wealthy local leaders (ayan, zuama), normally great landlords or merchants, whose extended families controlled certain urban quarters or villages. These parties were precipitated by the creation of parliaments where factions of deputies grouped together in "conservative" or "liberal" blocs supporting or opposing the government but seldom able to hold it accountable. Linked more by personal ties than ideology, they were ephemeral and vulnerable to factionalism. Able to count on the dependents of the notables, such as peasants on their estates or clients in urban quarters, to win elections, notable parties had little need for party cadres or organization. Classic examples of such parties were the LiberalConstitutionalists of Egypt, the various court parties in Morocco and Jordan, and the National and Constitutional blocs in Lebanon. In the early Iranian majlis, caucuses (maslaks) of royalists and liberals appeared.

The main initial opposition to the upper class notable parties emerged as a still-small Westernized middle class emerged. New parties formed, led by intellectuals and professionals, often teachers and their students, professing liberal or radical ideologies, often organized around a political newspaper, and, in the 1930s, sometimes giving birth to fascist-inspired militant youth groups (Green Shirts, Blue Shirts). Such parties were often able to mobilize student demonstrations and influence educated political opinion but, lacking the great wealth to establish clientalist networks in a era prior to mass politicization, they remained relatively small urban groups and were seldom able to win elections. Mustafa Kamil's National Party in Egypt, the Iraqi Istiqlal party, the Democrat Iran party, and the early Ba'th party are good examples. ${ }^{4}$

Where nationalist agitation spurred political mobilization, certain early parties evolved into large-scale independence movements, normally combining coalitions of notables, groups of intellectuals and students mobilized by nationalist ideology, with elements of the lower classes brought in through street agitation or the clientele networks of the notables. Some became formidable electoral machines, able to win parliamentary majorities through a combination of nationalism in the 
cities and clientalism in the villages. The Egyptian Wafd and the Moroccan Istiqlal, Mossadeq's National Front in Iran, and the Syrian Kutla (National Bloc) all came close to representing the whole nation against the imperialist power. ${ }^{5}$ However, their mobilization of a socially heterogeneous base around the single issue of independence doomed most of them to fragment after independence when they tended to lose their intellectual activists and their mass bases (as happened to the Moroccan Istiqlal from which the National Union of Popular Forces seceded) or to factionalize (thus, the Syrian Kutla split into the Damascus-centred Watani and the Aleppo-centred Sha b parties). The major exception was the Tunisian Neo-Destour Party whose charismatic leadership and exceptional organizational capacity enabled it to make the transition to a ruling single party.

As, from the forties to the sixties, the educated middle class grew and politicization spread to the rural peripheries, several parties of intellectuals were able to develop and fill the vacuum left by the decline of notable parties. The key to this was an ability to bridge the middle class-mass and urban-rural gaps by propagating nationalist and populist ideology and developing formal organization with branches in the provincial towns. They included several secular nationalist parties such as Egypt's Misr al-Fatat (Young Egypt, later the Socialist Party of Egypt), the Syrian Social Nationalist Party (SSNP), ${ }^{6}$ the National Democratic Party in Iraq, the National Socialists of Jordan, and the Arab Socialist Ba'th Party in Syria and Iraq. All combined ideologies mixing nationalism and reformist socialism and support among middle class professionals, army officers and growing student populations with footholds in trade unions and peasant movements. At the same time, Communist parties attempted to organize the emerging working classes, achieving temporary successes in Iran, Egypt and Syria; but they were quite vulnerable to ideological factionalism, state repression and delegitimation on nationalist grounds and in some cases remained too rooted in certain ethnic minorities. Finally, widely imitated across the region was the Muslim Brotherhood of Egypt which, attracting activists from religious students and support from the petite bourgeoisie (small merchants, artisans, clerks) and recent migrants to the city, demonstrated the ability of Islamic ideology and militants to build a well-organized mass base, including cooperatives, charities and paramilitary organizations. ${ }^{7}$

The ideological and organizational power of the Brotherhood, the communists and the Ba'thists was demonstrated by their ability to spread across state boundaries. Although still partly leader-dependent (the Egyptian Ikhwan temporarily declined after the supreme guide was killed), their remarkable durability amidst state repression and generational change in leadership indicated considerable organizational and ideological institutionalization. However, in agrarian societies where notables and tribal chiefs kept much of the mass public encapsulated in their clientele networks, none of these parties were normally able to mobilize the electoral majorities needed to take power constitutionally (although some entered into coalition governments with parties of notables); and most therefore flirted with attempts to subvert and use the military to gain power.

Party development took somewhat different forms in different states. In the post-World War II period when the Iranian political system was rapidly liberalized, a number of significant parties were founded. The Democrat Party, a catch-all party including both landowners and intellectuals and centred around the personality of veteran politician Ahmad Qavam al-Saltaneh, actually won a majlis majority in 1947. 
The Iran Party was a liberal grouping of intellectuals. The Marxist Tudeh Party, possessing both middle class and worker activists and the most disciplined organization, led the trade unionisation of Iran's emerging industrial working class after World War II. Mossadeq's National Front (Jebhe-ye Melli), an umbrella movement of notable parties and middle class parties of intellectuals rather than an organized mass party, nevertheless dominated the majlis in the early 1950s on the strength of its nationalist program and charismatic leader. ${ }^{8}$ This pluralism was cut short by the 1953 re-imposition of royal autocracy.

In Iraq, middle class parties could not make breakthroughs into the notabledominated parliament but developed outside and against it. These included the Istiqlal, followers of Arab nationalist veteran Rashid Ali al-Gaylani, and the liberal National Democratic Party, which grew out of the earlier Ahali group of intellectuals. After the 1958 revolution there was a dramatic expansion in participation as the now-tolerated Communist party, recruiting from intellectuals, the working class and the Shi a urban poor, rapidly grew to 25,000 members by 1959 while the Kurdish Democratic Party mobilized the Kurds, both tribal and intellectual, and the Ba'th Party incorporated lower-middle class Sunnis. The degeneration of this pluralism into near-anarchy invited unstable military rule until the consolidation of the Ba'th Party regime after $1968 .^{9}$

Lebanon is a limiting case where pluralism survived beyond the fifites--even into the post-Uprising period; yet communal fragmentation deterred the emergence of a mature party system in spite of the state's liberal political structures. Instead, earlier primitive proto-parties adapted and were later joined by mass movements with communal bases. The first proto-parties were the "blocs" of notables (zuama), typically parliamentary caucuses linked to society through clientele networks rather than extra-parliamentary organization. To be sure, in parliamentary elections from 1951-72, the representation of true party-affiliated deputies climbed from $10 \%$ to $30 \%$ of the seats, but, where successful, parties were almost always clan-led and were only able to mobilize cross-class mass support by ideologizing a sectarian appeal. The most durable such party was the Maronite Kataib (or Phalanges) led by the Gemayal clan, which mobilized the Maronite bourgeoisie, the petite bourgeoisie and parts of the peasantry, in opposition to other sects but also often against the main Maronite zuama. Other similar but less organized parties included the National Liberals (of the Maronite Chamouns), the Druze-dominated Progressive Socialists (of the Junblatts) and the Dashnak party representing Armenian Christians. The Muslims were represented by zuama blocs inside parliament and outside it were regionally fragmented into urban quarter-based Nasserite or Sunni Islamic groups. Even the communist party factionalized along sectarian lines between Orthodox Christian and Shia factions. During the civil war from 1975, party militias, pushing aside the zuama, ruled "cantons" and collected taxes, with the Lebanese Forces, a Kataib offshoot, controlling most Maronite regions and the Shia militias, Amal and Hizbollah, emerging to dominate the Muslim regions. In the post-Taif 1992 elections, however, zuama domination revived, with only 39 of 108 parliamentary deputies being party-affiliated; this election did, however, register the post-civil war change in the sectarian balance of power: the Shia Hizbollah and Amal movements, reinvented as parties, won 12 seats, the largely Orthodox Christian SSNP 4, the Dashnak 4 and the Progressive Socialists 4, with the Maronite parties self-excluding themselves. ${ }^{10}$ 
Single party systems and Revolution from above

In a second phase (1950-60s) of party development, middle class political leaders, variously originating in middle class parties and/or the military, established single party systems as instruments of "revolution from above." Where this happened, many of the parties of the liberal period disappeared, although some, such as the Ba'th, reinvented themselves as ruling single parties. According to Huntington, the single party system originates in a bifurcation between the revolutionary regime and "traditional" society (or the old oligarchy), its function to both concentrate power in the hands of the revolutionary elite (and exclude the oligarchy from power) while expanding power by mobilizing a mass constituency. The revolutionary struggle substitutes for party competition in keeping the party dynamic and the ruling elite responsive; where there is little such struggle, the single party tends to be weaker and as conflict with the old oligarchy declines, so does the party's responsiveness to its mass constituency. Indeed, as the party elite becomes part of a new upper class, the party starts to change from an instrument of revolution into a patronage machine (through which clients seek favours and careerists upward mobility). ${ }^{11}$

Single parties aspired to be mass parties penetrating the peripheries and organizing the masses, but they varied widely in their ability to do so. What Owen ${ }^{12}$ calls "rallies and unions" were relatively weak parties established by military leaders from above (such as the Liberation Rally and National Union in Egypt, the Arab Liberation Movement of Syrian dictator Adib Shishakli and the Arab Socialist Unions (ASU) established by military leaders in Egypt, Iraq, Sudan and Libya). In these parties, ideological commitment was unimportant and nominal membership was extended to virtually the entire population except for active opponents of the regime; this made these organizations vulnerable to infiltration by many contradictory vested interests, even those unsympathetic to the regimes' reform programs. Such parties were not elite recruitment mechanisms, with the military and bureaucracy remaining the career paths to the top. On the contrary, party offices at the centre and province were staffed by ex-military officers and bureaucrats "on loan" rather than by political activists; the top layers of the party hierarchy were thus a mere auxiliary of the bureaucracy, incapable of channelling participation or aggregating interests. Harik calls this sort of organization a "collaboration movement" because at the local level it coopted notables (and their clientele networks) who were allowed a relatively free hand in their locales in return for acquiescence in the regime but had no say in national policy; as such, these parties were also crippled as mobilizational instruments. Those leaders who wanted to carry out a revolution in the village soon became dissatisfied with and tried to transform such organizations. Thus, Nasser tried to reinvigorate the ASU by recruiting a cadre of young militants on ideological grounds to displace or balance the village notables but abandoned the effort after the 1967 war. In Libya Muammar Qaddafi attempted to invigorate his mass organization by encouraging a "cultural revolution" against the bureaucrats and tribal leaders and by recruiting ideological militants into "revolutionary committees" meant to "guide" the wider mass membership. ${ }^{13}$

Stronger single party regimes resulted when the party, through a history of grassroots struggle, acquired a cadre of militants and some roots in the population 
prior to the assumption of power. Subsequently, party leaders normally adopted a "Leninist" strategy of party building from top down, in which ideological militants recruited from plebeian strata established party cells in villages, factories, and schools, while creating or taking over labour, peasant and youth unions. The ruling party acquired a full time professional apparatus, and a pyramid of congresses, partly elected, partly co-opted, linked base and centre. The party might share power with a charismatic leader and/or the military, but the sign of its "strength" was its greater centrality in the performance of political functions than in the "rally" form of single party. Thus, the party organization was a major ladder of recruitment into the political elite, its top congress, representing the regime elite assembled, had some role in policy making, the party normally subordinated and supervised the government bureaucracy in the implementation of policy and, at the local level, party militants played a key role in social reforms, notably land reform. The Destour Socialist Party in Tunisia, the Yemen Socialist Party (previously National Liberation Front) in former Democratic Yemen, and the ruling Ba'th parties in Syria and Iraq approximated this model. The decline of the party tended to be accompanied by its displacement from policy making, by the ascendancy of the military over it (as in Syria under Asad), by its transformation into a creature of personal rule (as in Iraq and Tunisia) or by its degeneration into personal and tribal factions (as in former Democratic Yemen where the party violently self destructed along such lines).

The Algerian FLN was mid-way between the weak and the strong types of single party systems. Algeria's struggle for independence gave birth to a succession of mass parties that expressed the dominant nationalist and Islamo-populist political culture. The FLN (Fronte Liberation Nationale), began as a guerrilla organization mounting armed insurrection and evolved into an umbrella absorbing almost all pre-existing political groups. In this process, the FLN was factionalized and after independence, its constituent parts were absorbed into the army and bureaucracy or went into opposition, leaving it a moribund shell subordinated to the military. In the seventies, President Boumediene revived the FLN as a bureaucratic apparatus with 10,000 party workers, controlling the mass organizations and charged with carrying out his "agrarian revolution." Its congress was, moreover, the formal arena in which the succession of President Chadli Ben Jedid was brokered.

None of the single party systems succeeded in wholly eliminating opposition. Rather, Islamist parties, whether variants or offshoots of the Muslim Brotherhood or Shia analogues, such as the Dawa party in Iraq, representative of the marginalized merchants and ulama, tended everywhere to survive or emerge underground, from where, facing represson by regimes, some attempted--unsuccessfully--violent insurgency in the 1980s-90s.

\section{Limited party pluralism under Post-Populist Authoritarianism:}

In the next phase of development beginning in the seventies, the region was dominated by post-populist republics or monarchies under which a dominant president or monarch allowed limited scope for political pluralism. Such states were associated with two main types of party system, the "dominant party system" (in which the ruling single party permits small opposition parties) and the "palacedominated multiparty system."

The dominant party system was an outcome of the partial liberalization in the authoritarian republics beginning in the seventies. As the populist consensus 
that accompanied single party rule collapsed and rulers began to economically liberalize against the resistance of statist interests while populations threatened by this turned to political Islam, regimes sought to mobilize social forces favourable to liberalization, find ways to co-opt opposition, and trade limited participation rights for public acceptance of the gradual abandonment of the populist social contract. Their strategy, a limited pluralization of the party system was, arguably, an adaptation to the ideological pluralization of the political arena. This liberalization allowed some of the earier parties marginalized under single party rule, to reemerge, e.g. the Egyptian Wafd party was reborn as the "New Wafd Party."

Egypt after Nasser is the best case of the dominant party system in the Middle East. As Egypt's Nasserite consensus dissolved, the all-embracing ASU was disbanded in 1976 and some of its fragments or the remnants of pre-revolutionary parties allowed to constitute themselves as "loyal" opposition parties. While the presidency remained the centre of authoritarian power and the ruling party never failed to win a large parliamentary majority, opposition parties were allowed to compete, not for governing power, but for access to power (e.g. parliamentary seats). While the government party sought to straddle the centre of the political spectrum, opposition parties flanked it on the left and right. The ruling National Democratic Party (NDP), was a direct descendant of Nasser's ASU, incorporating the ruling alliance of senior bureaucrats, top police and army officers, businessmen, and the provincial landed notables, albeit shorn of the left-wing intellectuals and politicized officers who briefly dominated the ASU. The NDP's ideology of a mixed economy was compatible with both the public sector in which many bureaucrats and state managers had a stake and the growing role of private and foreign capital from which both officials and pro-regime businessmen were being enriched. A stream of initiatives and responses to government from its parliamentary causus sought to defend or promote the particular interests of elements of its largely bourgeois constituency while providing its MPs access to patronage.

More an appendage of government than an autonomous political force, the party enjoyed little loyalty from its members, had few activists, hence only a primitive organization. This reflected its lack of interest in mass mobilization; if anything, its function was to enforce demobilization. As such, it had to depend on village headmen and local notables to bring out the vote; it also lacked financial resources to back its candidates who depended on personal resources to run their campaigns and on their ability to deliver government patronage to attract votes. Nevertheless, by way of the clientele networks of the notables it co-opted, the NDP brought a portion of the village and urban masses into the regime camp, denying the opposition access to them; it also nominally incorporated large numbers of government employees and, an instrument of corporatism, placed its partisans in the top posts of many of the professional and labour syndicates.

An array of opposition political parties seemed to give expression to different interests and values than those of the ruling party. More than personalistic factions, they either revived some pre-Nasser political tradition or were rooted in a major societal or issue cleavage, and the rough correspondence between their ideologies and their social bases seemed for awhile to be moving Egyptian politics beyond a mere competition of patrons and shillas without social roots. Two liberal parties grouping landlords and wealthy professionals positioned themselves to the "right" of the ruling party: the tiny Liberal (Ahrar) Party and the New Wafd, the voice of the 
old aristocracy excluded from power by Nasser and of the wing of the private bourgeoisie still antagonistic to the state. On the left, the National Progressive Unionist Party (NPUP) or Tagammu brought together, behind an ideology of nationalist populism, a coalition of Marxist and Nasserite intellectuals and trade union leaders under the leftwing ex-Free Officer, Khalid Muhy ad-Din. It had a small but well organized base of activists, but the regime, in intimidating trade unionists into distancing themselves from it, robbed it of its putative mass constituency and it later degenerated into a government-aligned faction opposed to political Islam. The Socialist Labour Party (SLP), a descendent of the radical nationalist pre-1952 Misr al-Fatat, began as a defender of the public sector and critical of Western alignment, but, lacking a mass base, moved into close alignment with the Muslim Brotherhood under the slogan "Islam is the solution." The Brotherhood itself, never legalized as a party, nevertheless stood candidates as independents or under the SLP banner. Led by ulama and wealthy merchants, it was silent on the regime's economic liberalization but highly critical of its Western alignment. While the movement was weak among industrial workers and peasants, it was strongly attractive to more "marginal" elements such as educated unemployed rural migrants and the traditional mass of small merchants and artisans who wanted an "Islamic economy" that accepted private property and profit but sought to contain their inegalitarian consequences by a moral code and a welfare state. The Brotherhood was differentiated from smaller more radical Islamic groups by its willingness to proselytise peacefully within the political system.

The representative potential of a dominant party system required opposition parties become "parties of pressure" representing constituencies left outside the ruling coalition in order to pressure the government to adopt parts of their programs. The potential for such a system peaked in the most open and competitive elections of 1984 and 1987. In 1984 the New Wafd and the Muslim Brotherhood formed a joint ticket that captured 58 of 448 seats with 15 percent of the vote and emerged as the main opposition forces; in 1987 the New Wafd, competing alone, got thirty five seats, while the small Liberal and Labour parties, joined with the Muslim Brotherhood in the Islamic Alliance, won sixty. Thus, while the government majority remained unchallengeable, the liberal and Islamist interests emerged as a significant opposition presence in parliament where, however, instead of combining against the government, the first advocated economic and political liberalization and the second won Islamization concessions from the secular regime.

However, the regime stopped short of allowing (and even reversed) the political freedoms needed to expand party pluralization to the level of the mass public and make the opposition parties effective parties of pressure. The government's manipulation of electoral laws, its monopoly of the broadcast media, restrictions on the opposition's ability to campaign and associate, intimidation of opposition activists and the often fraudulent administration of elections all enforced the message that the opposition would not be allowed to translate its potential support over issues into votes and seats in parliament. The low turnout for elections indicated that many Egyptians were unconvinced that voting under these conditions made any difference to political outcomes; those who did vote, behaving rationally, voted according to a candidate's perceived ability to deliver patronage, a resource largely controlled by the regime. 
In this situation, the government party was able to co-opt the local notables with the best personal followings and family alliances who, knowing they had to deliver government patronage to retain their seats, were deferent toward it. Because opposition parties also needed to deliver patronage they too tended over time to mute their opposition. The one exception to the enervation of the opposition parties was the Muslim Brotherhood which alone possessed a significant cadre of activists, independent financial resources, and real organization; precisely for this reason it became the main target of government repression, suffering massive arrests of its cadres at election time, which effectively contained its electoral potential. In general, thus, the pluralization of the party system actually reinforced the regime: elections functioned to co-opt and channel political activity that might otherwise have taken a covert, even violent, anti-regime direction into more tame, manageable forms. Additionally, the divisions in the opposition generally allowed the regime to play off secularists against Islamists, left against right. ${ }^{14}$

Limited republican pluralism took country-specific variations in Yemen and Iran. The unification of the two Yemeni single party states resulted at first in a unique co-habitation between the two ruling parties, the conservative-tribalist People's General Congress of the north and ex-Marxist Yemen Socialist Party of the south, later joined by the Islamic Islah party; before long however they fell out in a violent civil war in which the socialists were marginalized. ${ }^{15}$ Different yet was postrevolutionary Iran where the single party, the Islamic Republican Party, never more than an umbrella for disparate groups, dissolved into several clergy-led networks each of which expressed the views of distinct societal constituencies, "reformists," "centrists" and "conservatives." In this proto-multiparty system, electoral competition was real and came to turn on issues, first the struggle between populist radicals and economic pragmatists; then that between cultural conservatives and liberals. The impact of the electorate on outcomes has, however, been filtered by the "checks and balances" of the non-elected theocratic part of the political system-the religious leader and the council of guardians which vets electoral candidates.

The transformation of a single party system into a dominant party system was by no means easy or inevitable. In Algeria, the ruling FLN failed to maintain its dominance and the opposition FIS (Front Islamique du Salut) won the first liberalized elections by mobilizing all those excluded from state patronage networks. Based on thousands of mosques, its cadre of imams preached against government corruption, appealing to the commercial strata (who financed the organization), and to the educated unemployed and recently urbanized. The military's repression of the FIS after it won the 1991 elections left Algeria without an effective party system and opened the door to civil war. Tunisia's move toward pluralism similarly failed, with the repression of the Islamists resulting in continued nearly-single party rule. ${ }^{16}$ Where the single party was particularly strong, as in Iraq and Syria, it left even less room for associatinal activity outside its corporatist institutions and the Ba'th regimes therefore made only cosmetic concessions to pluralization--sacrificing the opportunity to fully incorporate new social forces, such as crony capitalists and Islamist movements, via "authoritarian upgrading."

A second type of limited pluralism is the palace-dominated fragmented party system. In the liberal era, constitutional monarchy appeared to be evolving in Morocco, Jordan, Iran and Kuwait. Parties competed for parliamentary seats; however, when they challenged royal authority to pick and dismiss governments, 
king's dissolved parliaments, even closed down party politics and assumed "personal rule." Indeed, parallel with the 1960s regional move away from pluralism, this happened in all the above monarchies. However, this actually provoked greater instability: attempted coups in Morocco, riots in Jordan, and revolution in Iran. In reaction, and along with the post-populist re-pluralization across the regon in the 1990s, monarches reintroduced a "palace pluralism" in which multiple party competition was arbitrated by a monarchy "above" partisan politics.

Monarchic pluralism is most authentic in Morocco. More than in Egypt, the main parties have programs, organizations and substantial constituencies. In the fifties the Istiqlal, the mass independence party led by veteran nationalist Allal alFassi, had 250,000 active members, branches at the grassroots level and full time party officials; if, at its core, it was the party of the traditional urban bourgeoisie, its vague nationalist ideology allowed it to incorporate a broad societal cross-section, including the urban poor. Its main weaknesses, typical of such independence parties, was an urban centeredness that left the rural (and Berber) hinterland in the hands of conservative notables who tended to support the monarchy; and its inability to prevent the post-independence breakaway of many of its more radical activists and trade union cadres who formed the National Union of Popular Forces (NUPF).

Above the parties, the monarchy, having stood up to the French, had a nationalist legitimacy unique among monarchs, while also controlling the levers of state patronage and of repression (including an army disproportionately recruited from Berber tribes). The king, possessed of these resources and exploiting the Istiqlal's weaknesses, was able to avoid a choice between repression of all party pluralism and letting a majority party or coalition control the government. Rather, he was able to preserve the right to make and unmake governments while allowing enough party pluralism to satisfy participatory pressures.

The king sustained royal power by dividing and forcing parties to compete for his favour. To be played off against the urban-centred opposition parties, there was always a party of the "king's men," recruited from the high bourgeoisie and the traditional rural Berber tribes. Ironically, the main parties fragmented precisely over whether to play the king's game, with the NUPF splitting from the Istiqlal over its refusal to play and it itself later eclipsed by breakaway elements that were willing to do so (which formed the Socialist Union of Popular Forces). Thus, Morocco's party evolution has been away from a single mass party toward increasing party fragmentation and weakness, a reflection of the declining mobilizational capacity of the parties and the divide and rule policy of the king.

Under this system, the parties do have a role in providing the ministerial elite and in mediating between the king and people. The king tolerates this limit on royal sovereignty because he found the narrowing of his support under personal rule invited instability (attempted coups), and because limited pluralism actually helped, as Zartman argued, to consolidate the regime. Their participation in the system not only co-opts the party elite but, because their inclusion requires they moderate the demands of their constituencies, it tends to weaken their societal support to the king's benefit. Yet, parties have regularly demonstrated sufficient electoral support that the king has felt obliged to include them in government or, alternatively, to take the wind out of their sails by co-opting their demands as his own; in this sense they function as "parties of pressure" serving as crucial safety valves by ensuring some responsiveness to interests outside the establishment. Even when the parties have 
turned radical and resorted to strikes that have degenerated into urban insurrection over economic deprivation, they have been useful to the king in that examples are made of them: jail terms for their leaders, followed by amnesty and possibly cooptation. Thus, the Moroccan monarchy has been able to simultaneously tolerate partisan activity and remain in control of it by an assiduous exploitation of the societal cleavages expressed by the fragmented party system. ${ }^{17}$ Party pluralism in Kuwait and Jordan was also tolerated as part of monarchs' cooptation strategies.

The regions' experiments in controlled party pluralism produced hybrid regimes that, rather than being a transitional period on the road to democratization, were a substitute for it. Limited party pluralism, wherein some were included and others excluded, allowed regimes to play a more sophisticated form of divide and rule. ${ }^{18}$ But the opposition parties, not just the regimes, were themselves part of the problem in that their dependence on personalities, un-democratic internal life and rapid proliferation and fragmentation rendered them unable to promote, support or hold accountable democratic governments.

An Alternative Trajectory: Democratization via Mass Competitive Party Systems:

Parallel to the hitherto described developments in most MENA states, the Middle East's most socio-economically "advanced" societies, Turkey and Israel , advanced along a different trajectory of democratization, in which mass incorporating competitive party systems played central roles. The two cases also illustate how the alternation in power of ruling and opposition parties is central to the formation and accountability of governments and how the party configuration is crucial to governments' effectiveness.

Turkey's transition from a single to a two-party system in the 1950s remains the prototype for democratization in the region. Each of the two rival parties that emerged incorporated distinct social constituencies: the formerly ruling Republican Peoples Party (RPP) centred on retired military officers, urban bureaucrats and intellectuals, while the new opposition Democrat Party (DP), led by businessmen and rural notables, appealed to the rural majority. Competitive elections made a difference, for example, in allowing peasant voters to force governmental responsiveness to formerly neglected rural interests. Societal and parliamentary support enabled the majority DP to sustain stable government for a decade. ${ }^{19}$

The two main parties proved remarkably institutionalized, surviving leadership and ideological changes and forced reconstructions during periods of military intervention. The RPP survived the transition to a two party system, a long period in opposition in the fifties, and a transformation in its leadership to professionals and intellectuals and of its base to urban white and blue collar workers, becoming, under Bulent Ecevit, a social democratic party. The Democrat Party, although mutating into several new incarnations, notably the Justice Party (JP), could be said to have survived several leadership changes while still representing the same broad business-rural coalition.

After 1960, the two party system evolved into a multi-party system, reflective of the deepening mobilization and polarization of society, with smaller more radical parties emerging on the left and right and speaking for those dissatisfied by the two main centrist parties. In addition, periodic military interventions that briefly banned and forced parties to reconstitute themselves, weakened the parties. After the 1960 intervention, the Islamic National Salvation 
party, mobilizing imams and religious students as grass roots activists, built an effective organization that incorporated a constituency among small businessmen and artisans, becoming the third largest party. The National Action party, an authoritarian nationalist, Pan-Turkist party with some middle class and youth support exercised disproportionate influence owing to its pivotal role in making up centre-right coalitions in the seventies. In this period, the JP and RPP alternated pluralities but the JP was more successful in forming governing (centre-right) coalitions. Intensified party competition and the accompanying scramble for state patronage led to ineffective coalition governments and fiscal deficits that opened the door to political instability and the 1970 and 1980 military interventions.

After the 1980 intervention, the party system became increasingly fragmented. The centre-right split into the Motherland party (neo-liberal, Anatolian based) and the True Path party (descendent of the Justice party). The centre-left was divided by rival personalities between the Democrat Left Party of Ecevit, Erdel Inonu's Social Democratic Populist Party, and Deniz Baykal's Republican Peoples Party. Thus was ushered in another period of weak coalition governments, increasingly discredited in public eyes, which ended in the implosion of all the parties except the Islamic Justice and Development Party (AKP) (descendent of the Islamic Salvation, for a period the Refah Party) that won a parliamentary majority in the 2002 elections. Its successful formation of a government, in the face of the Islamophobia of the military, was a test of the power of political parties.

In Israel, party development took a similar course. Two strong parties, the dominant leftwing Mapai (later Labour), incorporating the trade unions, and the rightist Herut (later Likud) were initially permanent ruling and opposition parties. By the eighties, they were alternating in power or occasionally joining in national unity governments. Simultaneously, however, the polarization of society led to fragmentation of the vote and the party system, hence a disproportionate weight acquired by small extremist parties in unstable coalition governments. The result was an on-going paralysis in foreign policy that obstructed the prospects for Middle East peace. Party weakness was paralleled by the increasing co-optation of exgenerals into party leadership. ${ }^{20}$ The Israeli and Turkish cases show that, as mass politicization turns into democratization, party capacity determines the effectiveness and stability of government and where party capacity does not keep up with political mobilization, weak governance results.

Party Systems and the Arab Uprising: between Democratization, Restoration and State Failure

In the decade beginning in 2000, de-stabilization swept the Middle East, beginning with the 2003 US invasion of Iraq and culminating in the Arab Uprisings, starting in 2010 that challenged authoritarian regimes in the name of democracy. Party systems alone did not determine whether regimes were vulnerable to the Uprising; thus, in Morocco and Egypt dominant party systems led to dissimilar outcomes and single party systems gave way to democratization in Tunisia and to civil war in Syria. But states' party systems nevertheless had some bearing on the trajectories-democratization, old regime restoration or civil war-that they took.

Thus, in Syria, Bashar al-Asad debilitated the Ba'th party, seen as a hindrance to his power consoldtion and economic reforms; this inadvertently weakened his regime's organized connection to its constituency, making it vulnerable to anti- 
regime mobilization. Still, the reconfiguration of the loyalist Ba'th party remnants as armed militias helped prevent regime overthrow, resulting, instead, in civil war. In Iraq, the US "de-Bathification"--dissolution of the Ba'th party, hence also of the intertwinded army and bureaucracy"--was the direct cause of state failure and exBa'th cadres played a role in subsequent insurgencies against the new anti-Ba'th Baghdad regime, including that of ISIS. By contrast, Qaddafi's no-party system ended in total regime collapse. Party debilitation was in factor in state failure.

Further, the configuration of party systems was decisive in determining whether democratic transitions were consolidated or reversed, producing dramatically different outcomes in three iconic cases, Turkey, Egypt and Tunisia. Democratization faltered when individual parties were either too strong (Turkey) at the expense of the party system or too weak (Egypt). Only in Tunisia did the makings of a two party system have the potential to consolidate democratization.

In Turkey, the party system since the 1970s had been notoriously weak, producing fragmented parliaments and coalition governments that allowed the military to dominate until the AKP won majorities in several successive elections in the 2000s. The causes of AKP success was its conservative yet democratic version of Islam, combined with neo-liberal policies such as privitizations of state owned enterprises, that appealed to a cross-class constituency, linking the Anatolian capitalist class to the pious provincial middle and lower classes. Economic growth after several economic crises consolidated the party's position as a dominant party within a multi-party system.

The consequences were in one respect positive for democracy: government that could govern and enjoyed popular support, but had, nevertheless to face regularly accountability to the electorate; and the ability of a strong ruling party to marginalize the endemic military intervention in politics. On the other hand, the AKP party leader, Erdogan gradually assumed a majoritarian notion of democracy in which he interpreted electoral mandates as enabling him to curtail opposition criticism, liberties, and press freedoms. Turkey seemed to slide into electoral authoritarianism in which the ruling party abused its power; yet, even as the economy faltered and Erdogan's policy of intrervention in the Syrian Uprsing, generated damaging blowback, the party escaped electoral reverses largely because the rest of the political spectrum was so sharply divided, with opposition parties on the right and left of the AKP having little capacity to act together as an effective loyal opposition. Even when the AKP lost its overall majority in the 2015 election, it was able to exploit public fears of instability (which it had helped foster), to call a new election and recover its absolute majority. If Turkey's democracy was initiated by a balanced two party system and came close to failure amidst fragmented multipartism, it was now threatened by regression to a semi-democratic dominant party system.

Meanwhile, in Egypt the opposite outcome-a very weak party system that emerged in the post uprising period--opened the door to a restoration of the old regime under overt military leadership. In initial elections, the Muslim Brotherhood, organized in the Justice and Development Party, and the salafists, organized in the Nour party, proved themselves to be the most effective vote-getters, possessing electoral machines or networks constructed under Mubarak's limited pluralist opening, that penetrated mass neighbourhoods (while the remnants of the old NDP-local notables and their clientele networks--chose to lay low at this time). By 
contrast, the secular older generation parties such as the NPUP, Nasserites and Wafd had, over time, shrunk and splintered and initially played little role in the uprising while the new youth movements that had spearheaded it likewise splintered in its aftermath; both lacked the organizational capacity to mobilize mass voters. As a result, they could not compete with the Islamist parties who dominated the post first post-Mubarak assembly or in the post-Mubarak presidential elections matching the Muslim Brotherhood's Muhammed Morsi and the old regime candidate Muhammed Shafiq who delivered the remnants of Mubarak's constituency. Unable to compete with the Islamists, the liberal secularists chose to join ranks with the military to oust Morsi, the democratically elected president. After Morsi's overthrow, loose pro-Sisi coalitions delivered votes using the networks and techniques of the old NDP to produce a parliament filled with "president's men." Counter-revolution had triumphed owing to the inability of the revolutionary factions and secular parties to organize themselves into an effective party coalition able to mobilize the mass followings that might have allowed them to balance the military and the Islamists.

In Tunisia, two major parties competed for power in the post-Ben Ali era. The moderate Islamist an-Nahda, won the first election, ruling in coalition with a liberal party, an ability to share power that contrasts sharply with the other two cases. Its rule precipitated a broad counter-coalition, Nidaa Tounes, of disparite forces, united by secularism, including remnants of the old ruling party and the trade union movement. An apparent two-party system seemed emergent, giving the electorate a choice between two parties capable of governing. The subsequest electoral victory of the Nidaa Tounes allowed the electorate to push the Islamists from power without destroying the democratic transition, as had happened in Egypt. The features of the party system were arguably pivotal to this outcome, namely the existence of two parties, each representative of a large segment of society, yet, able to contain ideological polarization and equal enough to feel confident they could defend their interests within an electoral system. ${ }^{21}$

\section{Conclusion: Parties in Middle East Politics}

The important role played by parties in the Middle East challenges "exceptionalist" claims that political culture deters wide-scale association there. Modernization changes culture, widening politicalization and reshaping the balance between impersonal (rational-legal /ideological) association and traditional forms of asabiyyah; thus, the spread of literacy, industrialization and class formation propelled politicization and the consequent development of large-scale parties, even if factional shillas and clientalism persisted inside formal party organizations. At the same time, parties had agency and were pivotal factors in the evolution of politics in the region, with party evolution paralleling regime formation. Table 1 summaries this parallel regime and party development.

In the early pluralist period, parties allowed individuals and groups to cooperate on a less asymmetric basis by comparison to the age-old clientele networks of the politics of notables. But early pluralism remained relatively limited to the upper and middle classes and seldom penetrated the rural areas. Party systems were debilitated by the extreme inequality in the distibution of wealth, notably land, and their failure to incorporate middle class support for the liberal 
order opened the door to the era of populist revolution from above. In Lebanon where, exceptionally, no such revolution marginalized the notability, the old party

Table 1: The Evolution of Political Parties in MENA

\begin{tabular}{|c|c|c|c|c|}
\hline Stages & $\begin{array}{l}\text { Arab } \\
\text { Republics }\end{array}$ & $\begin{array}{l}\text { Democracies: } \\
\text { Turkey and } \\
\text { Israel }\end{array}$ & Lebanon & Monarchies \\
\hline $\begin{array}{l}\text { Early } \\
\text { Oligarchic } \\
\text { Liberalism } \\
(1930-50)\end{array}$ & $\begin{array}{l}\text { Parties of notables } \\
\text { or intellectuals and } \\
\text { Middle Class } \\
\text { branch parties fail } \\
\text { to incorporate } \\
\text { middle classes }\end{array}$ & $\begin{array}{l}\text { Single and } \\
\text { Dominant party } \\
\text { systems in } \\
\text { Turkey and Israel }\end{array}$ & $\begin{array}{l}\text { Notable proto- } \\
\text { parties dominate }\end{array}$ & $\begin{array}{l}\text { In Moroccan, } \\
\text { Iranian and } \\
\text { Jordanian } \\
\text { constitutional } \\
\text { monarchies, } \\
\text { notable and mass } \\
\text { parties compete in } \\
\text { multi-party } \\
\text { systems }\end{array}$ \\
\hline $\begin{array}{l}\text { Populist } \\
\text { Revolution } \\
\text { from Above } \\
(1952-80)\end{array}$ & $\begin{array}{l}\text { Ruling Single } \\
\text { Parties in Egypt, } \\
\text { Iraq, Syria, Algeria, } \\
\text { Libya and Tunisia, } \\
\text { consolidate } \\
\text { populist } \\
\text { authoritarianism; } \\
\text { but also stimulate } \\
\text { underground } \\
\text { Islamist movements } \\
\text { among the excluded }\end{array}$ & $\begin{array}{l}\text { Mass two party } \\
\text { systems in Turkey } \\
\text { and Israel } \\
\text { enable } \\
\text { democratization; } \\
\text { multi-party } \\
\text { fragmentation } \\
\text { undermines it, } \\
\text { enabling periodic } \\
\text { military } \\
\text { intervention or } \\
\text { military-based } \\
\text { politicians }\end{array}$ & $\begin{array}{l}\text { Parties of } \\
\text { notables persist; } \\
\text { emergence of } \\
\text { mass militias and } \\
\text { Islamist } \\
\text { movements }\end{array}$ & $\begin{array}{l}\text { Monarchic } \\
\text { absolutism and de- } \\
\text { pluralization in } \\
\text { Morocco, Iran and } \\
\text { Jordan. }\end{array}$ \\
\hline $\begin{array}{l}\text { Post-Populist } \\
\text { Era (1980- } \\
\text { 2010) }\end{array}$ & $\begin{array}{l}\text { Post-populist } \\
\text { authoritarian } \\
\text { "upgrading" via } \\
\text { Dominant Party } \\
\text { Systems: ruling } \\
\text { single parties } \\
\text { flanked by re- } \\
\text { emergent notable or } \\
\text { middle class parties. }\end{array}$ & $\begin{array}{l}\text { Fragmented party } \\
\text { systems in Turkey } \\
\text { and Israel }\end{array}$ & $\begin{array}{l}\text { Parties of } \\
\text { notables, mass } \\
\text { militias and } \\
\text { Islamist } \\
\text { movements co- } \\
\text { exist }\end{array}$ & $\begin{array}{l}\text { Revolution } \\
\text { overthrows Iran's } \\
\text { monarchy; } \\
\text { Monarchic re- } \\
\text { pluralization in } \\
\text { Morocco, Kuwait } \\
\text { and Jordan; }\end{array}$ \\
\hline $\begin{array}{l}\text { Post Arab } \\
\text { Uprising } \\
\text { (200-- }\}\end{array}$ & $\begin{array}{l}\text { Weak party system } \\
\text { in Egypt congruent } \\
\text { with authoritarian } \\
\text { restoration; in Iraq, } \\
\text { Syria and Yemen } \\
\text { violent competition } \\
\text { between remnants } \\
\text { of ruling and } \\
\text { opposition Islamist } \\
\text { movements spell } \\
\text { state failure; in } \\
\text { Tunisia emergent } \\
\text { two-party system } \\
\text { enables democracy }\end{array}$ & $\begin{array}{l}\text { Unbalanced } \\
\text { competitive party } \\
\text { systems in Turkey } \\
\text { and Israel }\end{array}$ & $\begin{array}{l}\text { Parties of } \\
\text { notables, mass } \\
\text { militias and } \\
\text { Islamist } \\
\text { movements co- } \\
\text { exist. }\end{array}$ & $\begin{array}{l}\text { Monarchic } \\
\text { pluralism } \\
\text { proves immune to } \\
\text { Arab Uprising. }\end{array}$ \\
\hline
\end{tabular}

pattern persisted while in Turkey and Israel, a very different scenario--the emergence of mass incorporating two party systems--paralleled democratization.

With the 1960s rise of populist-authoritarian regimes, party organization proved an indispensable new "political technology" in the launching of "revolutions from above" that mobilized and organized large sectors of the middle and lower classes; authoritarian republics that did not develop an effective ruling party proved 
unstable, such as North Yemen and Iraq from 1958 to 1968. To be sure, party association by itself proved unable to consolidate these states and the resort of leaders to charisma and clientalism as supplementary political cement inside or parallel to formal institutions tended to debilitate political life within ruling parties; moroever such single parties always excluded the significant portions of the population damaged by revolution from above; these were the natural constituents of the underground Islamist movements that threatened to destabilize PA regimes. In parallel with republican authoritarianism, monarchies in Morocco and Jordan also sharply contracted the party pluralism of the earlier era.

Populist authoritarianism gave way, in the period of economic liberalization and "authoritarian upgrading" to "post-populist" regimes that initiated limited liberalization. In the republics, authoritarian presidents conceded opposition party formation within the ambit of dominant party systems that served as instruments of cooptation, clientelism and of divide and rule in the transition toward crony capitalism; in certain monarchies party pluralism played a similar role.

The failure of such limited party pluralism to satisfy more compex mobilized societies opened the door to the Arab Uprisings, but party configurations shaped subsequent outcomes. Where democratisation advanced, as in Turkey and postUprising Tunisia, its consolidaton depended on the emergence of a massincorporating two-party system and was threatened in Turkey by a seeming decline into a dominant party system. The contraction of the incorporative capacities of single parties in Syria and Iraq made them vulnerable to combinations of external intervention and internal revolt, but loyalist Ba'th party rumps or remnants prevented victory by anti-Ba'th opponents, leading to civil war and state failure. In Egypt party system weakness opened the door to restoration of a variant of the old regime. It is, therefore, apparent that party development is inextricably bound up with--and cannot be ignored in any convincing analysis of--political development in the Middle East.

\section{NOTES}

${ }^{1}$ Bill and Springborg, Politics in the Middle East, New York: HarperCollins, 1994, pp. 84-105, 235;

Fred W. Riggs, "Bureaucrats and Political Development: A Paradoxical View," in Bureaucracy and Political Development, Ed. Joseph LaPalombara. Princeton, NJ: Princeton University Press, 1967. 120-

67.

${ }^{2}$ Manfred Halpern, Politics of Social Change in the Middle East and North Africa. Princeton, NJ:

Princeton University Press, 1963, pp. 281-3.

${ }^{3}$ Samuel Huntington, Political Order in Changing Societies, Yale University Press, 1968, p. 398.

${ }^{4}$ Arthur Goldschmidt, “The Egyptian Nationalist Party, 1892-1919.” In P.M Holt (ed.), Political and

Social Change in Modern Egypt, London: Oxford University Press, 1968; George Jabbur, al-fikra al-

siyasi al-mu'asir fi Suriya [Contemporary Political Thought in Syria]. London: Riad El-Rayyes, 1987; 
James Jankowski,_Egypt's Young Rebels: “Young Egypt,”: 1933-1952. Stanford, CA: Hoover Institution Press, 1975.

5 Marius Deeb, Party Politics in Egypt: The Wafd and its Rivals, 1919-39. London: Ithaca Press, 1979

${ }^{6}$ Labib Zuwiyya Yamak, The Syrian Social Nationalist Party: An Ideological Analysis. Cambridge, Mass.: Harvard Center for Middle Eastern Studies, 1966.

${ }^{7}$ Richard Mitchell, The Society of Muslim Brothers, London, Oxford University Press, 1969.

${ }^{8}$ Richard Cottam, “Political Party development in Iran;” Iranian Studies 1 (3), summer, 82-95.

${ }^{9}$ Reeva Simon, "Iraq," In Frank Tachau (ed.), Political Parties of the Middle East and North Africa, London: Mansell, 1994, 174-97.

10 Michael Suleiman, Political Parties in Lebanon: the Challenge of a Fragmented Political Culture. Ithaca: Cornell University Press, 1967; John Entelis, Pluralism and Party Transformation in Lebanon: al-Kataib, 1936-1970. Leiden: E.J.Brill, 1975.

${ }^{11}$ Samuel P. Huntington, "Social and Institutional Dynamics of One-Party Systems." In Louis J. Cantori (ed.), Comparative Political Systems Boston: Holbrook Press, 1974, 323-70.

12 Roger Owen, State, Power and Politics in the making of the Modern Middle East. (London: Routledge 1992, pp. 255-72

13 Iliya Harik, "The Single Party as a Subordinate Movement: The Case of Egypt." World Politics, 26

(1), October.

${ }^{14}$ Raymond Hinnebusch, Egyptian Politics under Sadat, Boulder CO: Lynne Rienner Publishers, 1988, pp. 158-170, 186-222, 302-04; Maye Kassem, In the Guise of Democracy: governance in contemporary Egypt. Reading: Ithaca Press, 1999.

${ }^{15}$ Renaud Detalle, "Les parties politiques au Yemen: paysage après le bataille." Revue des Mondes musulmans et de la Mediterranee, 1996 81-2, 341-96.

${ }^{16}$ Jolly, Cecil 1995: “Du MTI a la Nahda [en Tunisie].” Cahiers de l’Orient, 38, 19-40.

${ }^{17}$ I. William Zartman, “Opposition as Support of the State”, In A. Dawisha and Zartman (eds.), Beyond Coercion: the Durability of the Arab State. London: Croom Helm for Instituto Affairi Internazionali, 6187.

${ }^{18}$ Ellen Lust-Okar, “The Decline of Jordanian Political Parties: Myth or Reality?” International Journal of Middle East Studies, 33 (4), 2001, 545-71. 
${ }^{19}$ Kemal Karpat, Turkey's Politics: The Transition to a Multi-Party System. Princeton, N.J.: Princeton University Press, 1959.

${ }^{20}$ Samuel J. Roberts, Party and Policy in Israel, Boulder, CO: Westview Press, 1990.

${ }^{21}$ Michelle Penner Angrist, "Party Systems and Regime Formation in the Modern Middle East:

Explaining Turkish Exceptionalism," Comparative Politics, 36: 2, Janaury 2004, 229-49 